\title{
Field testing and evaluation of a domestic biomass cookstove in rural small household industry
}

\author{
Suhartono ${ }^{1, *}$, Suharto ${ }^{2}$, Nurlaila Agustina ${ }^{1}$, and Hanna Hafidaturrohmah ${ }^{1}$ \\ ${ }^{1}$ Departement of Chemical Engineering, Universitas Jenderal Achmad Yani, Cimahi 40533, Indonesia \\ ${ }^{2}$ Research and Development Division for Mineral Technology, Indonesia Institute of Sciences, South Lampung 35361, Indonesia
}

\begin{abstract}
This work presents the performance parameters of a solid biomass cookstove for household industrial application to meet the parameters required by the National Standardization Agency of Indonesia (SNI 7926: 2013). The biomass stove design was tested using corncob, coconut shell and wood chips as biomass fuel. Thermal efficiency, combustion efficiency, specific fuel consumption, emission of $\mathrm{CO}$ and particulate emissions were evaluated. The combustion temperature, visual flame, combustion air requirement as well as economic evaluation were also studied as additional performance parameters. The average specific fuel consumption rate, $\mathrm{S}_{\mathrm{c}}$ of the stove was found $0.57 \mathrm{~kg} / \mathrm{h}$. The using amount of biomass variety on this stove could produce the maximum thermal power, $P_{\text {th }}$ of $24,75 \mathrm{~kW}_{\text {th }}$ and the average combustion efficiency, $\eta_{c}$ and the thermal efficiency, $\eta_{\text {th }}$ of $98.2 \%$ and $27 \%$, respectively. The flame temperature of $722-947^{\circ} \mathrm{C}$ was achieved at equivalence ratio, $\Phi=0.61-0.89$. The average $\mathrm{CO}$ and particulate production, $\mathrm{PM}_{2.5}$ on this biomass stove were $39.97 \mathrm{~g} / \mathrm{kg}$ and $0.9 \mathrm{~g} / \mathrm{kg}$, respectively. The difference of profit margin compared to liquid petroleum gas (LPG) utilization as fuel was about IDR 2,000/kg fish. All these parameters are met to SNI 7926:2013 and corncobs seem the most appropriate biomass fuel on the consideration of this test results.
\end{abstract}

\section{Introduction}

The rural people of Indonesia still use traditional solid biomass cookstove to fulfill their energy needs for cooking and heating. Rural areas of West Bandung District, West Java, Indonesia are very dependent on biomass fuels for their energy consumption. It was recorded at least 23 small household industries in this rural area. These households' industries have liquid petroleum gas (LPG) stoves are provided with two burners of about $3 \mathrm{~kW}_{\text {th }}$ maximum capacity, with operating efficiencies of about $60 \%$. According to previous studies, the LPG need of industry is about 35 $\mathrm{kg} /$ day [1], [2]. This use of energy was often replaced by solid biomass waste such as wood chips, corncob and coconut shell as fuel, due to the problems that are associated with LPG in term of high fuel cost and availability. Biomass has been a major source of household industries' energy in this rural area. Corncob is one of the agricultural waste as the alternative energy. The potential energy of corncob from agricultural plantations in this area was about $13.03 \mathrm{GWh}$ in a year [1]. In general, the waste biomass waste is used directly as fuel using conventional stoves that are characterized by low efficiency and wasteful biomass usage. These conventional stoves designs are batch type operating on the bulk of biomass fuel feeding on the top side. This stove is not scientifically designed resulting in the lower thermal efficiency of $20 \%$ [3] and to lead to severe health hazards due to indoor air pollution [4]. The present work is concerned with the utilization of local biomass wastes from agriculture crops residues especially corncob, coconut shell and wood chips as the energy source, hence to develop continuous operation biomass cook stove for fuel feeding and ash removal. The biomass stove was designed to be flexible to various types of biomass feeds and easy to operate and be able to the complete combustion by providing sufficient combustion air. The combustion temperature, visual flame, combustion air requirement and economic evaluation were also studied in this work. All tested parameters could meet the SNI 7926: 2013 standard [5].

\subsection{Biomass energy utilization}

Low cost and widespread distribution are one of the most important advantages attributed to the utilization of renewable energy of solid biomass. Solid biomass waste can be used as a source of renewable energy in the household and small industry sector for cooking in the rural area of West Bandung District, West Java, Indonesia. This solid biomass is crop residues from agricultural plantations such as corncob, coconut shell, and wood chips. This typical solid biomass has the ultimate analysis by mass as carbon content is 30 to $50 \%$, hydrogen is around $6 \%$, oxygen is 30 to $45 \%$, nitrogen is around $2 \%$ and $\mathrm{HHV}$ is about $17 \mathrm{MJ} / \mathrm{kg}$ [1], [6-8]. The estimation of this solid biomass energy

\footnotetext{
* Corresponding author: suhartono@lecture.unjani.ac.id
} 
potential is about 27,295.2 GJ in a year [1], [2]. As an example, the corncob waste from agricultural plantations in this area was estimated at 11,960 tons/year with potential energy approximately 46,903,064 MJ/year [1]. In general, the solid biomass waste is utilized directly as fuel by combustion using an inefficient conventional simple stove and while the rest is used for other purposes.

Solid biomass cook stove is essentially combustion devices that enable converting solid biomass to gaseous fuel by a thermochemical conversion process. This combustion process involves drying, pyrolysis, oxidation, and reduction reactions between the solid biomass and air at sustainable elevated temperatures to release heat. The produced heat is transferred to the cooking vessel by cook stove. This combustion process is affected by the physicochemical properties of solid biomass and quantity and mode of air supply [9], [10]. The process involves evaporation of the moisture contained in the biomass, then the biomass begins to pyrolyze to produce a combustible gas by the complex thermo-chemical reaction. The combustible gas typically contains $16 \% \mathrm{CO}, 12 \% \mathrm{H}_{2}, 3 \% \mathrm{CH}_{4}, 12 \% \mathrm{H}_{2} \mathrm{O}$ (as gas), some higher hydrocarbons (5-6\%) and remaining being $\mathrm{N}_{2}$ [11], [12]. The proportion of these components is influenced by the chemical compositions of solid biomass being fed and the operating conditions of the cook stove. At the upper side of the biomass stove, the combustible gas allowed to mix with the secondary air supplied directly through naturally inducing air to combust with flame. The secondary air is introduced ambient air as the hot air rises (natural draft). This flame temperatures from this biomass combustion can exceed $2000^{\circ} \mathrm{C}$

The inefficient combustion of solid biomass can lead to the formation of pollutants such as carbon monoxide (CO) and particulates. Incomplete combustion due to various factors leads to inefficient combustion. The combustions are fuel/air ratio, mode of biomass supply and primary and secondary air supplies are the technical factors to control the perfect combustion in solid biomass stove. The addition amount of secondary air is needed to achieve complete combustion. The amount of secondary air needed depends on the fuel properties and the stove configuration [6].

\subsection{Biomass stove design}

The natural convection mode with the primary and secondary combustion airports and continuous feeding of fuel were the basic principle design of this stove [13], [14]. The sufficient combustion air by the adequate draft was consideration of stove design to enhance the combustion quality. The stove design was developed to be implemented in a small household industry on the basis of the total operation time of $1.5 \mathrm{~kg}$ corncob. The energy requirement fuel consumption rate, $\mathrm{S}_{\mathrm{c}}$ of 5.0187 $\mathrm{kg} / \mathrm{h}$ was used to estimate the stove dimensions. The diameter and height of combustion chamber estimated were estimated based on these values. A solid biomass stove was constructed using mild steel sheet with $8 \mathrm{~mm}$ thickness. The primary and secondary ports were provided for incoming air supply. A rectangular aperture of fuel on the side edge near the bottom of the stove is provided for the continuous feeding of fuel. The biomass cookstove consisted of four main parts i.e., ash discharge collector, fuel storage (loading fuel door), primary air, combustion chamber, secondary air inlet and pot support and it has a grate installed at above of its bottom. Ash from combustion chamber could fall down freely through the grate and accumulated in an ash collector. The geometry of the stove was intended to ensure a good combustion quality. The cookstove combustion chamber was made two cylinders in inner and outer diameter stove were $15 \mathrm{~cm}$ and $13.5 \mathrm{~cm}$, respectively. The total stove height was $45 \mathrm{~cm}$ with a height of $35 \mathrm{~cm}$ combustion chamber. The loading fuel door size of $5 \mathrm{~cm}$ $\mathrm{x} 12 \mathrm{~cm}$, equipped with 12 and 40 holes of primary and secondary air inlet with a diameter of each hole was 2 $\mathrm{cm}$ and $8 \mathrm{~mm}$, respectively. The details of the solid biomass cookstove are shown in Figure 1. The implementation of this improved biomass stove has been proven to meet SNI's parameters and reduce the LPG utilized.

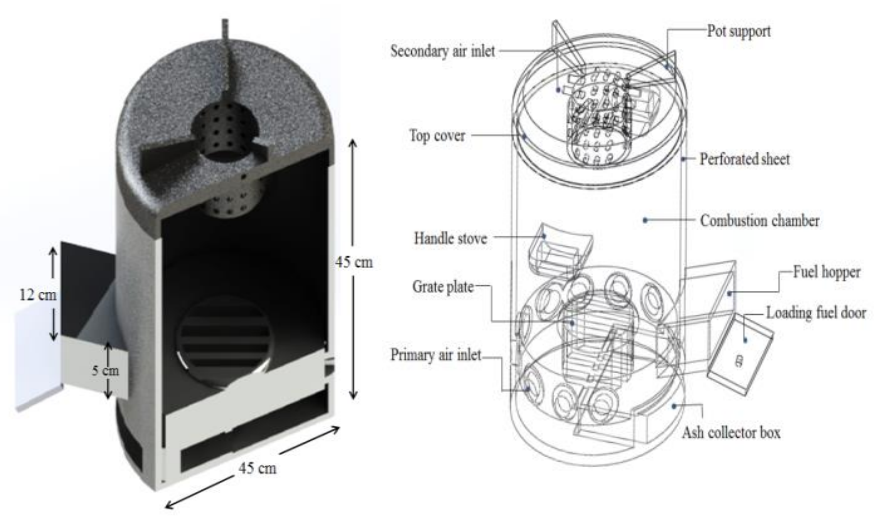

Fig. 1. Isometric view of the biomass stove

\section{Experimental methods}

The three kinds of biomass waste as feedstock of corncobs, coconut shells, and wood chips were used for stove evaluating. The biomass stove was cut into small pieces and store in a dry place for further use. Proximate analysis of fuel was carried out before the test by using the method suggested by ASTM D3173-11. Also, the calorific values of four fuels were determined with help of bomb calorimeter as per ASTM-711.

The fuel consumption rate, $S_{c}$ was measured by recharging the stove on the basis of total operation time. The biomass weight of about $0.5,1.0$, and $1.5 \mathrm{~kg}$ were used in the test to measure the startup time and the fuel consumption rate. The fuel consumption, $\mathrm{S}_{\mathrm{c}}$ was calculated using the equations below [5], [15].

$$
S_{c}=\frac{\Delta m_{k}}{\Delta t}
$$

where $\Delta \mathrm{m}_{\mathrm{k}}$ is the fuel mass that has been burned during the test $(\mathrm{kg})$ and $\Delta_{\mathrm{t}}$ is the duration of the test. 
The grate at the bottom of the chamber allows inflow of air into the combustion area due to the natural draft. The combustion air will move naturally from low temperatures to high temperatures due to the difference in density. The low-temperature zones on the stove will have greater air density than in higher ones. The primary and secondary ports were provided to measure the amount of air required. The air combustion flow rate was measured using a digital anemometer Krisbow-KW06653. Above the grate was the biomass chamber from where the ash flowed down by its gravity to ash collector. The ash accumulated was removed regularly during the tests. The flame temperature test was conducted by replacing the probe of k-type digital thermocouple Krisbow-KW06-283 about $10 \mathrm{~cm}$ above the fire zone. The flame temperature was recorded during the test for various biomass combustion in the stove.

The weighing electronic balance BL220H series (weighing capacity; $220 \mathrm{~g}$ accuracy; $0.001 \mathrm{~g}$ ) with a digital display was used for determination of the mass of the biomass before and after burning. The difference in weight shows the total consumption of fuel, which gives the indication of average firepower. The thermal power, $\mathrm{P}_{\text {th }}$ was calculated by using the following formula [4], [9], [15], [16]:

$$
P_{\text {th }}=m_{f} \cdot L H V_{\text {biomass }}
$$

where $P_{t h}$ is the fire power, $\mathrm{kW} ; \mathrm{m}_{\mathrm{f}}$ is the mass loss rate of fuel, $\mathrm{kg} / \mathrm{s}$, and $\mathrm{LHV}_{\text {biomass }}$ is the lower calorific value of the biomass fuel, $\mathrm{kJ} / \mathrm{kg}$.

The biomass consumption was evaluated by frying a quantity of food until cooked and a known quantity of water was heated using thermal power from the stove as the standard water-boiling test and controlled-cooking test (CCT) [2], [17]. The experiments were conducted by measuring amount heat absorb for boiling amount of water at atmospheric pressure (at about $100^{\circ} \mathrm{C}$ ) and for frying amount of food until cooked (at the boiling point of cooking oil, about $250{ }^{\circ} \mathrm{C}$ ). The amount of beat absorbed by the fuel dividing by the total amount of fuel used was defined as the thermal efficiency, $\eta_{\mathrm{T}}$ and calculated using the following adopted mathematical formula [3], [4], [9], [15], [16], [18] :

$$
\eta_{T}=\frac{\left(m_{w} C_{p w}+m_{v} C_{p v}\right)\left(T_{f}-T_{i}\right)}{m_{f} L H V_{\text {biomass }}} \times 100
$$

Where $\mathrm{m}_{\mathrm{w}}$ is the mass of water taken in the vessel, $\mathrm{kg}$; $\mathrm{m}_{\mathrm{v}}$ the mass of aluminum vessel, $\mathrm{kg}$; $\mathrm{cp}_{\mathrm{v}}$ specific heat of aluminum vessel, $\mathrm{kJ} / \mathrm{kg} / \mathrm{K} ; \mathrm{cp}_{\mathrm{w}}$ the specific heat of water/food, $\mathrm{kJ} / \mathrm{kg} / \mathrm{K} ; \mathrm{T}_{\mathrm{f}}$ the boiling temperature of water/oil, $K ; \mathrm{T}_{\mathrm{i}}$ the initial temperature of water, $\mathrm{K} ; \mathrm{m}_{\mathrm{f}}$ the mass of fuel consumed, $\mathrm{kg}$ and $\mathrm{LHV}_{\text {biomass }}$ is the lower calorific value of fuel used, $\mathrm{kJ} / \mathrm{kg}$.

The perfect combustion of biomass was defined as the combustion efficiency, $\eta_{\mathrm{T}}$ and indicated by the minimum level of carbon monoxide in the flue gas stream (exhaust). The combustion efficiency, $\eta_{c}$ was calculated from the concentration of carbon monoxide (CO), $\mathrm{N}_{\mathrm{CO}}$ and carbon dioxide $\left(\mathrm{CO}_{2}\right), \mathrm{N}_{\mathrm{CO} 2}$ in the flue gas. In order to collect flue gas, suction cap (a cyclone set) was located at the center above the stove equipped with the gas analyzer Testo $380 \mathrm{XL}$ to measure $\mathrm{CO}$ and $\mathrm{CO}_{2}$ emitters. The combustion efficiency, $\eta_{\mathrm{c}}$ was calculated using the following equation [5].

$$
\eta_{c}=1-\frac{N_{C O}}{N_{C O 2}}
$$

Particulate matter in a flue gas with a maximum size of 2.5 microns $\left(\mathrm{PM}_{2.5}\right)$ was measured using a 2.5 -micron filter paper and use a micron scale. The following formula was used to calculate particulate matter [5]:

$$
P M=M F_{f}-M F_{i}-m_{b k} \times t_{c}
$$

$\mathrm{MF}_{\mathrm{f}, \mathrm{i}}$ and $\mathrm{m}_{\mathrm{bk}}$ are the mass filter and the average mass of particulate collection (ppm), respectively and $t_{c}$ is the test time (h). All the parameters have to meet the SNI parameters: specific fuel consumption, $\mathrm{S}_{\mathrm{c}}$; emission of $\mathrm{CO}$ and particulate emissions, $\mathrm{PM}_{2,5}$ should not exceed; $1 \mathrm{~kg} / \mathrm{h}, 67 \mathrm{~g} / \mathrm{kg}$ and $1500 \mathrm{mg} / \mathrm{kg}$, respectively. The minimum of the combustion efficiency, $\eta_{\mathrm{c}}$ and the thermal efficiency, $\eta_{\text {th }} ; 0.96\left(\mathrm{~N}_{(\mathrm{CO})} / \mathrm{N}_{(\mathrm{CO} 2)}<0,04\right) 0.96$ and $20 \%$, respectively [5].

The theoretical combustion air requirement for biomass combustion was calculated on the basis of the elementary content of each biomass. Air flow through the stove was dependent on the decreased density air after combustion heat addition. This actual combustion air requirement was measured by the superficial flow rate of air suction entering the primary and secondary air holes using digital anemometer. The air/fuel ratio for a stoichiometric mixture and actual air/fuel ratio, $\mathrm{kg}_{\text {air }} / \mathrm{kg}_{\text {fuel }}$ were defined as $\mathrm{AFR}_{\text {stoch }}$ and $\mathrm{AFR}_{\text {act }}$, respectively [1], [4], [18]. AFR $\mathrm{Astoch}_{\text {is }}$ the ratio of the amount of air necessary to combust all of the fuel to carbon dioxide $\left(\mathrm{CO}_{2}\right)$ and water $\left(\mathrm{H}_{2} \mathrm{O}\right)$ with no excess oxygen $\left(\mathrm{O}_{2}\right)$.

The mixing of the fuel and air prior to the flame creates a mixture strength that is characterized by an equivalent ratio designated by the Greek letter phi $(\Phi)$. In this work, the equivalent ratio, $\Phi$ was used to estimate whether that combustion of solid biomass was dominated by combustion mode or pyrolysis mode by using the equation (6).

$$
\Phi=\frac{A F R_{\text {stoch. }}}{A F R_{\text {act. }}}
$$

If more than a stoichiometric quantity of air is supplied, the mixture is defined as lean, $\Phi<1$, while supplying less than the stoichiometric air results in rich, $\Phi>1$. For a stoichiometric mixture, $\Phi$ equal to unity.

\section{Biomass stove field testing}

\subsection{Combustion properties of biomass}

The characteristics and thermal utilization of biomass combustion are influenced by structural components and 
chemical elements of its biomass. $\mathrm{C}, \mathrm{H}$, and $\mathrm{O}$ are the main components of solid biomass waste depending on the origin and type of biomass. Calorific value is the one the main biomass indicators as it refers to the heat released from the fuel during combustion. The amount of carbon (C) and hydrogen (H) content contributes positively to the calorific value of biomass as fuel. $\mathrm{C}$ and $\mathrm{H}$ oxidized during combustion by exothermic reactions to form $\mathrm{CO}_{2}$ and $\mathrm{H}_{2} \mathrm{O}$. The element analysis $\mathrm{C}, \mathrm{H}, \mathrm{N}, \mathrm{S}$, $\mathrm{O}$ and ash content of the different type of biomass are shown in Table 1. In this work, it is seen that by increasing $\mathrm{C}$ and $\mathrm{H}$ content in biomass, higher calorific value increases.

Table 1. Proximate and ultimate analysis of biomass waste

\begin{tabular}{|c|c|c|c|}
\hline & Corncob & $\begin{array}{c}\text { Coconut } \\
\text { shell }\end{array}$ & Wood chip \\
\hline Moisture, \% wb & 14.1 & 10.1 & 7.31 \\
\hline Volatile, \% db & 68.52 & 64.60 & 74.75 \\
\hline Fix carbon, \% db & 15.91 & 11.21 & 17.09 \\
\hline & & & \\
\hline Elements, \%w : & & & \\
\hline $\mathrm{C}$ & 42.01 & 64.23 & 49.90 \\
\hline $\mathrm{H}$ & 6.70 & 4.89 & 5.90 \\
\hline $\mathrm{O}$ & 48.10 & 22.61 & 41.80 \\
\hline $\mathrm{N}$ & 1.50 & 4.77 & 0.61 \\
\hline $\mathrm{S}$ & 0.24 & 3.51 & 0.07 \\
\hline $\mathrm{Ash}$ & 1.70 & 14.2 & 1.17 \\
\hline & & & 350 \\
\hline Bulk density, $\mathrm{kg} / \mathrm{m}^{3}$ & 340 & 562 & 19.56 \\
\hline Calorific value, $\mathrm{MJ} / \mathrm{kg}$ & 18.10 & 22.43 & \\
\hline
\end{tabular}

The coconut shell has the higher $\mathrm{C}$ and $\mathrm{H}$ content than corncob and wood chip. The calorific value is highest in coconut shell than the other two biomass types caused by higher of $\mathrm{C}$ and $\mathrm{H}$ content. The carbon concentration is correlated with calorific value, with each $1 \%$ increase in carbon elevating the calorific value by approximately $0.39 \mathrm{MJ} / \mathrm{kg}$ [6]. It is seen in the amount of carbon content of coconut shell causing also increased its calorific value. However, the ash content in coconut shells causes a slight reduction in its calorific value. The ash content decreases the net calorific value, because of moisture and ash absorb some of the heat. On the other hand, the relatively low amounts of ash in corncob and wood chip will increase the calorific value significantly. The content of hydrogen in corncob and wood chip affects the lower calorific value of its biomass due to the formation of water from the reaction of hydrogen and oxygen.

The ash content of the fuel is an essential consideration in the selection of suitable stove designs due to fly ash formation and ash deposit formation. The fly ash emissions formed are influenced by the amount of ash-forming elements in the biomass fuel. The utilization/disposal depend on the ash content of the biomass fuel, biomass with low ash content are therefore preferable.

Wood usually contains relatively low amounts of ash, while significantly higher values are typically found in the coconut shell. The corncob had a low bulk density compared to the wood chip and coconut shell. Biomass with low bulk density is required for easy of combustion air supplied. Therefore, corncobs and wood chip seem more suitable to utilize as fuel using this biomass stove. During the test, the coconut shell encountered many difficulties due to its high ash content. Accumulated ash was taken out through the grate by means of an ash collector box. With the falling ash, some burnable char particles were also carried away by the falling ash to ash collector, the lower efficiency of the stove with coconut shell fuel was due to higher combustible loss with ash.

Oxygen content in biomass also relates to calorific value, the higher content $\mathrm{O}$ content decreases the calorific value. The fuel with lower degrees of oxidation, tend to raise the heating value of the biomass. A certain amount of oxygen is required for complete combustion, with 14,022 J released for each $g$ of oxygen consumed for complete combustion [6]. Corncob and wood chip has a smaller heating value $(18.10 \mathrm{MJ} / \mathrm{kg})$ and $(19.56$ $\mathrm{MJ} / \mathrm{kg})$ than coconut shell $(22,43 \mathrm{MJ} / \mathrm{kg})$, because of its higher degree of oxidation. However, the thermal efficiency of a combustion system is not determined by the fuel quality in terms of the high heating value of the fuel. It does not mean that biomass with low calorific value, system efficiency will be lower than the use of biomass with higher calorific value. The combustion availability is a measure of the maximum energy that can be obtained from a fuel. This can be seen effectively when the ideal (perfect) combustion is achieved which is represented by the maximum temperature, surface flame temperature, and other parameters. The maximum efficiency depends not only on the calorific value of the fuel. Maximum efficiency can be indicated on the basis of flame temperature. The higher the flame temperature, the higher the theoretical maximum efficiency. Since the properties of this biomass are still within the range of biomass properties in general. It is reasonable to be used as the basis for calculating the parameters for evaluating the performance of the natural draft stove.

\subsection{Thermal power and efficiency}

In this work, the bulk density of corncob, coconut shell, and wood chips were found about of $340 \mathrm{~kg} / \mathrm{m}^{3}, 562$ $\mathrm{kg} / \mathrm{m}^{3}$ and $350 \mathrm{~kg} / \mathrm{m}^{3}$, respectively. Base on each nominal biomass fuel loading of $1.5 \mathrm{~kg}$, the combustion time of $15.5 \mathrm{~min}$., $20.21 \mathrm{~min}$. and $15.4 \mathrm{~min}$. were attained. This amount of biomass provided fuel consumption rates, $F_{c}$ of $5.02 \mathrm{~kg} / \mathrm{h}, 4.09 \mathrm{~kg} / \mathrm{h}$ and 4.67 $\mathrm{kg} / \mathrm{h}$ and the maximum thermal power, $\mathrm{P}_{\text {th, max. }}$ levels were set at $24.08 \mathrm{~kW}_{\text {th }}, 24.75 \mathrm{~kW}_{\text {th }}$, and $23.84 \mathrm{~kW}_{\text {th }}$, respectively. This implies that if biomass fuel of a higher density was loaded, one gets larger combustion time [19]. The fuel consumption rate, $S_{c}$ was lower for coconut shell compares to corncob and wood chips which may due to the high density of the fuel. In addition to bulk density, non-uniform size and shape of biomass and empty space in combustion chamber on the stove had a little effect on fuel consumption rate. This was evidenced when the stove was loaded with different amounts of biomass fuel, as shown in Figure 2.

It is often disadvantageous to have too high a fuel consumption rate. For comparison, the lowest consumption rate of LPG fuel is $0.12 \mathrm{~kg} / \mathrm{h}$, in this work. 
This means that the biomass utilized as fuel requires a more efficient stove for cooking to replace LPG stove and traditional stoves. The efficiency can be accomplished using this biomass stove design on the basis of lower fuel consumption rate and larger combustion time.

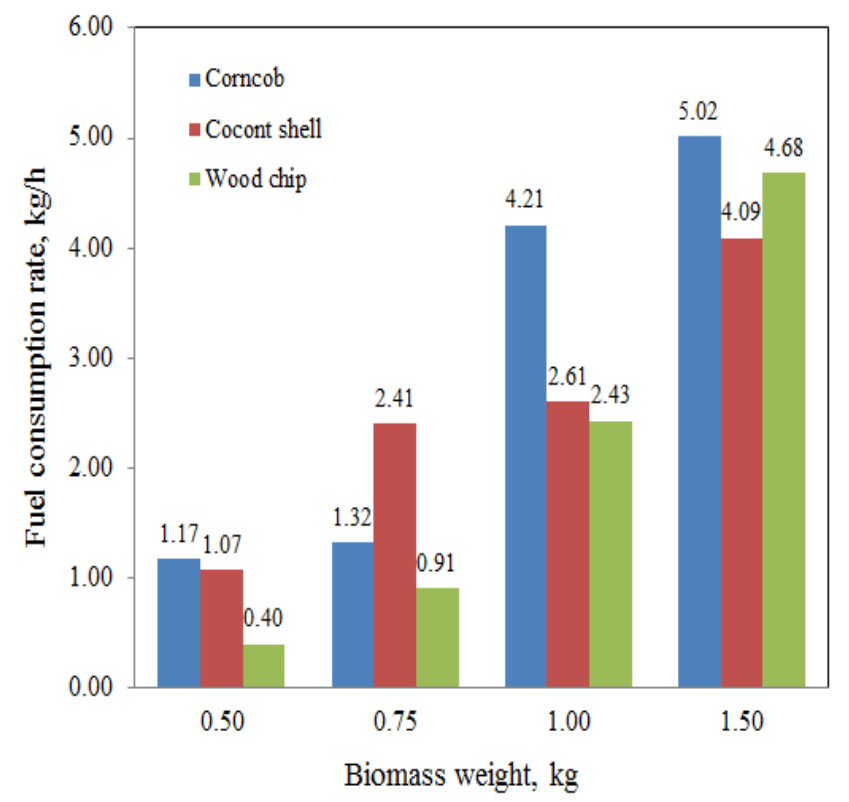

Fig.2. Fuel consumption rate of the different amount of biomass

A fuel/stove combination can be characterized by a thermal efficiency, thermal power, and flame temperature. The assessing stoves in a range of power settings and to distinguish between good and bad performance is indicated by these parameters. The average thermal power input, thermal efficiency and flame temperature for the fuel/stove combination are listed in Table 2. As a comparison of this work, Sood, et al (2018) reported the current developed cook stove in natural convection using mango sticks biomass as fuel. The maximum flame temperature and average thermal efficiency of $17.44 \%$ and $894{ }^{\circ} \mathrm{C}$, respectively were attained in this studied [14].

The thermal power input was calculated based on specific fuel consumption of the fuel amount needed to boil the amount of water. The medium of water through which the heat is transferred was used to calculate the thermal efficiency according to the water-boiling test method. The utilized of various amount of corncob, coconut shell, and wood chip gave an average combustion time of $0.26 \mathrm{~h}, 0.28 \mathrm{~h}$, and $0.38 \mathrm{~h}$, respectively. The average time for boiling $1000 \mathrm{~g}$ of water was $4.20 \mathrm{~min} ., 4.02 \mathrm{~min}$ and 3.55 respectively, gave the average specific fuel consumption rate, $S_{c}$ of $0.57 \mathrm{~kg} / \mathrm{h}$.

In this parametric study, wood chip showed better performance in term of combustion time, thermal power input and thermal efficiency. In this work, coconut shell exhibits lower combustion time than the wood chip. This behavior is caused by higher ash content and therefore the thermal power of coconut shell is lower than wood chip due to the low volatile release rate [4] (Table 1).
The combustion of volatiles is generally quite rapid and follows as fast as volatiles are released. The biomass size also has an effect on combustion, thick biomass will combust slowly causing the residence time in the combustion chamber becomes longer. Thus, to meet certain performance criteria of a particular thermal power level, the size, ash content and volatile matter content of biomass fuel should appropriately identify. In this case, the highest temperature of coconut shell combustion did not necessarily lead to higher thermal efficiency. This was because of required more fuel for cooking the same amount of water and high temperatures also caused a lot of heat loss.

Table 2. The fuel/stove combination characterized

\begin{tabular}{|c|c|c|c|c|}
\hline $\begin{array}{c}\text { Biomass } \\
\text { fuel }\end{array}$ & $\begin{array}{c}\text { Specific fuel } \\
\text { consumption } \\
\text { rate, }\left(\mathbf{S}_{\mathrm{c}}\right), \\
\mathrm{kg} / \mathrm{h}\end{array}$ & $\begin{array}{c}\text { Thermal } \\
\text { power } \\
\text { input } \\
\left(\mathbf{P}_{\text {th,in }}\right) \\
\mathbf{k W}_{\text {th }} \\
\end{array}$ & $\begin{array}{c}\text { Flame } \\
\text { temperatu } \\
\text { re }\left(\mathbf{T}_{\mathrm{f}}\right),{ }^{\circ} \mathrm{C}\end{array}$ & $\begin{array}{c}\text { Thermal } \\
\text { efficiency } \\
\left(\eta_{\text {th }}\right), \%\end{array}$ \\
\hline \multirow{4}{*}{ Corncob } & 0.38 & 5.610 & 797 & 25.24 \\
\hline & 0.42 & 6.340 & 722 & 18.31 \\
\hline & 0.82 & 20.20 & 795 & 9.40 \\
\hline & 0.98 & 24.08 & 874 & 10.14 \\
\hline Average & 0.65 & 14.06 & 797 & 15.78 \\
\hline \multirow{4}{*}{$\begin{array}{l}\text { Coconut } \\
\text { shell }\end{array}$} & 0.75 & 11.43 & 947 & 18.70 \\
\hline & 0.52 & 10.21 & 934 & 20.78 \\
\hline & 0.42 & 15.14 & 934 & 21.70 \\
\hline & 0.82 & 23.75 & 947 & 14.07 \\
\hline Average & 0.63 & 15.17 & 941 & 18.81 \\
\hline \multirow{4}{*}{$\begin{array}{l}\text { Wood } \\
\text { chip }\end{array}$} & 0.11 & 2.030 & 915 & 51.29 \\
\hline & 0.23 & 4.610 & 828 & 31.18 \\
\hline & 0.51 & 12.37 & 832 & 17.65 \\
\hline & 0.91 & 23.84 & 852 & 9.90 \\
\hline Average & 0.44 & 10.71 & 857 & 27.50 \\
\hline
\end{tabular}

\subsection{Combustion quality}

The adequate combustion air, flame temperature, and pollutant emissions can be taken as the indication of combustion quality. The sufficient air is required for the combustion reaction to produce a flammable gas to obtain maximum flame temperature and low pollutant emissions. The air draft was supplied through a large number of holes of small diameter. The superficial velocity of the biomass stove is one of the most important measures of its performance [19]. The observed total combustion air flow rate was in the range of $0.23 \mathrm{~m}^{3} / \mathrm{h}-0.45 \mathrm{~m}^{3} / \mathrm{h}$ as measured by superficial velocity and corresponds to $7.1 \mathrm{~kg}_{\text {air }} / \mathrm{kg}_{\text {fuel }}$ - 10.90 $\mathrm{kg}_{\text {air }} / \mathrm{kg}_{\text {fuel }}$. For each biomass, the stoichiometric combustion air was calculated based on $\mathrm{C}, \mathrm{H}, \mathrm{N}, \mathrm{O}$ analysis of the fuel. On the other hand, stoichiometric combustion air for each biomass was calculated on the basis of analysis of $\mathrm{C}, \mathrm{H}, \mathrm{N}, \mathrm{O}$ of fuel was in the range of $6.4 \mathrm{~kg}$ air $/ \mathrm{kg}_{\text {fuel }}-6.8 \mathrm{~kg}_{\text {air }} / \mathrm{kg}_{\text {fuel }}$. This stoichiometric air/fuel ratio is indicative of the stove is operating in the combustion mode. As a comparison, the air fuel for complete combustion of common biomass are 4 to 7 and for the certain biomass $\left(\mathrm{CH}_{1.4} \mathrm{O}_{0.6}\right)$ is approximately 6.3 [20]. Theoretically, The combustion reaches a maximum temperature when the air-fuel ratio permits all of the hydrogen and carbon in the fuel is burned to $\mathrm{H}_{2} \mathrm{O}$ and $\mathrm{CO}_{2}$ at $\Phi=1$. The optimum gasification mode is within 
the range of $\Phi=1.5-3.0$ [20]. For these three biomasses, the equivalent ratio, $\Phi$ is the range of 0.61-0.89 (Fuel lean mixture/excess air), indicates the minimum requirement of air for complete combustion has been met. Figure 3. shows a histogram of the equivalent ratio for the various amounts of biomass combustion against the resulting flame temperature. For all types of biomass combustion, equivalent ratio gets near to unity lead to increase the flame the temperature.

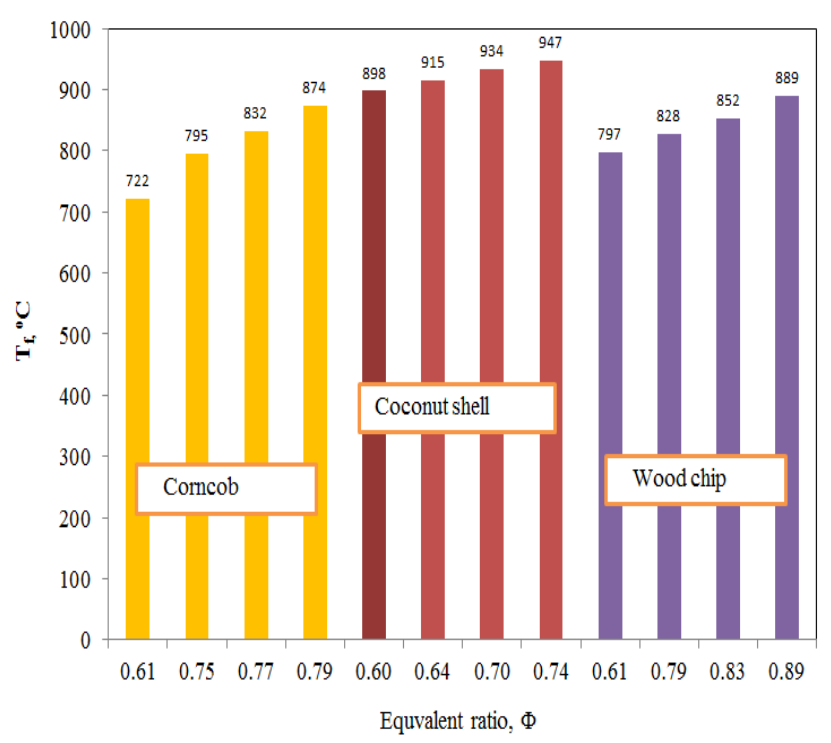

Fig. 3. Variation of flame temperature as a function of $\Phi$

It was found that the overall combustion temperature ranges from $722{ }^{\circ} \mathrm{C}$ to $947{ }^{\circ} \mathrm{C}$ and the appearance of flame color yellowish red and was consistent and was intense for all type biomass used, as presented in Figure 4. The slight change in color of the flame may be due to the moisture content and hydrocarbon in fuel being combusted in the combustion zone. The equivalent ratio determines whether the stove is operating in a complete combustion, while the flame temperature can be taken as the indication of the calorific value of the fuel and quantity of combustible gas produced [13].
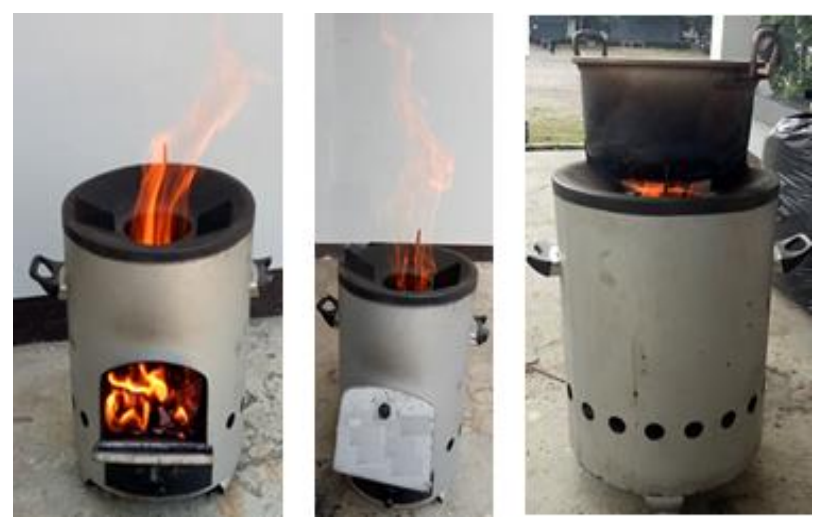

Fig. 4. Flame appearance

The flame temperature can be considered to be a function of fuel quality and to be dependent on the parameters of the conditions of the fuel-combustion process [21]. According to the obtained results and referred to Table 1, the biomass calorific value directly proportional to the increase in the flame temperature. In this case, the coconut shell with the highest calorific value of $22.43 \mathrm{MJ} / \mathrm{kg}$ can produce the constant highest temperature of $947^{\circ} \mathrm{C}$. The flame temperature shown by the corncobs was also constant but lower in value than that of wood chip. It can be concluded that constant temperature can be obtained in this designed stove by utilized this biomass.

Theoretically, the maximum thermal power condition can be achieved when $0 \%$ excess air ratio $(\Phi=1)$ is an exactly sufficient air is supplied for combustion of the current fuel [13]. The equivalent ratio increases tend to approach stochiometric combustion which is indicated by the flame temperature which tends to increase as well. In Figure 3, it can be seen that, the smaller equivalent ratios when operating at lower thermal power input (small fuel loaded) and slightly higher as the thermal power input increase. It can be explained that when a small amount of fuel allows the air faster supply due draft flow because of the sufficient free space on the stove. However, the higher equivalent ratio, $\Phi>1$ (fuel rich mixture/air deficiency) lead to increase quenching and cooler combustion temperatures might promote incomplete combustion and reduced thermal efficiency.

The pollutant emissions generated by combustion critically related to the properties of biomass as fuel [15]. Some important indicator of pollutant emissions is carbon monoxide, $\mathrm{CO}$ and particulate matter, $\mathrm{PM}$. In this work, emissions of $\mathrm{CO}$ were measured and calculated subsequently defined as particulate matter-specific emission ( $\mathrm{g}$ of particulate matter/kg of fuel burned) [13] and emission factor $\left(\mathrm{NCO} / \mathrm{NCO}_{2}\right)$. The average results of $\mathrm{CO} / \mathrm{CO}_{2}$ ratio and $\mathrm{PM}_{2.5}$ (particulate material with the diameter lower than $2.5 \mathrm{~mm}$ ) are shown in Table 3.

Table 3. Combustion efficiency and emission factors of the stoves for various types of biomass fuel

\begin{tabular}{|l|c|c|c|}
\hline Biomass fuel & $\mathbf{P M}_{\mathbf{2 . 5}} \mathbf{( g / \mathbf { k g } )}$ & $\mathbf{N}_{\mathbf{C O}} / \mathbf{N}_{\mathbf{C O} 2}$ & $\begin{array}{c}\text { The combustion } \\
\text { efficiency, } \boldsymbol{\eta}_{\mathbf{c}}(\mathbf{\%})\end{array}$ \\
\hline Corncob & 0.9 & 0.028 & 97.2 \\
\hline Coconut shell & 1.3 & 0.015 & 98.5 \\
\hline Wood chips & 0.6 & 0.011 & 98.9 \\
\hline Average & $\mathbf{0 . 9}$ & $\mathbf{0 . 0 2 8}$ & $\mathbf{9 8 . 2}$ \\
\hline
\end{tabular}

The emissions of $\mathrm{CO}$ and particulate matter is strongly affected by the excess combustion air (expressed by higher of $\Phi$ value), the higher excess air the lower CO emissions. Carbon monoxide is mainly released due to the incomplete combustion of biomass during the smoldering phase. In this stove, low $\mathrm{CO}$ emission levels can be obtained in the optimal range of excess air that minimizes CO production. In this work, The combustion efficiency of the stove decreased with increase in moisture content of fuel (see Table 1). The increased moisture content of biomass also leads to an increase in $\mathrm{CO}$ emission factors. An increase in $\mathrm{CO}$ emission factor appears to be caused by a decrease in the rate of gas reaction (oxidation) at a reduced temperature due to higher moisture content (see Table 1 and Table 2). The averaged results of $\mathrm{CO} / \mathrm{CO}_{2}$ ratio are shown Table 3 , which showed that during most of the operation period, the $\mathrm{CO} / \mathrm{CO}_{2}$ ratio was below 0.04 , which is well within the permissible value prescribed by SNI 7926:2013 [5]. 
As benchmark, the composition of $\mathrm{CO} / \mathrm{CO}_{2}$ ratio of about 0.03 using the recent developed cook stove in natural convection for different feedstock was given by Sood et al (2018) [14]. In further work, this stove will be equipped with a flue gas cleaning system using absorbent graphite waste modified with $\mathrm{Fe}_{3} \mathrm{O}_{4}$ adsorbent magnetite nanoparticles to reduce more levels of $\mathrm{CO}$ and $\mathrm{CO}_{2}$ emissions [22].

Particulate emissions, $\mathrm{PM}_{2.5}$ was released at higher thermal power due to the lower amount of flaming combustion (volatile matter in Table 1) which leads to reduced production of PM. Therefore, the highest PM emission factor is on combustion of coconut shell compared to the other biomass. The following average emission factors of $\mathrm{PM}_{2.5}$ and combustion efficiency, $\eta_{\mathrm{c}}$ were 0.9 and 98.2 of biomass combustion using this stove, respectively. These meet the requirements of the Indonesian standards and hence are considered acceptable. In addition to the average total mass of $\mathrm{CO}$ emitted during the entire test using corncob, coconut shell, and the wood chip was $42.1 \mathrm{~g} / \mathrm{kg}, 39.2 \mathrm{~g} / \mathrm{kg}$, and $38.6 \mathrm{~g} / \mathrm{kg}$, respectively.

\subsection{Economy}

Along with the performance evaluation of biomass stove field testing, economic studies was also the aimed of this research. The economy was conducted on the basis of the performance evaluation of this biomass stove for the cooking amount of fish by the controlled cooking method, CCT. This method differs from the WBT in the medium through which the heat is transferred. In contrast to water in the WBT, food is used as a medium in CCT [17]. Fuel consumption, Sc was used as the ratio of the amount of fuel needed to cook the fish (meal). By assuming the cost of biomass utilized for $1 \mathrm{~kg}$ of fish (meal) is about IDR 250, the selling price of this food product is around $15,000 / \mathrm{kg}$ fish. Meanwhile, the utilization of LPG as fuel will give the selling price of this product is around IDR $17,000 / \mathrm{kg}$ fish. The difference of profit margins between the using of biomass as fuel and LPG fuel was about IDR 2,000/kg fish.

\section{Concluding remarks}

Some parameters as the performance of biomass stove have been tested. The parameter such thermal power, $\mathrm{P}_{\text {th }}$, specific fuel consumption, $S_{c}$; combustion efficiency, $\eta_{c}$; thermal efficiency, $\eta_{\text {th }}$, and emission of $\mathrm{CO}$ and particulates, $\mathrm{PM}_{2.5}$ were evaluated using a design natural draft biomass stove. The additional parameter of equivalent ratio, $\Phi$ and flame temperature were also examined. The economic was also evaluated using the controlled cooking method, CCT on basis of an amount of frying fish. The stove performance parameters of specific fuel consumption rate, $\mathrm{S}_{\mathrm{c}}$, thermal power, $\mathrm{P}_{\mathrm{th}}$, thermal efficiency, $\eta_{c}$, thermal efficiency, $\eta_{\text {th }}, C O$ emission and particulate emissions, $\mathrm{PM}_{2.5}$ were 0.57 $\mathrm{kg} / \mathrm{h}, 24,75 \mathrm{~kW}_{\text {th }}, 98.2 \%, 27 \%, 39.97 \mathrm{~g} / \mathrm{kg}$ and $0.9 \mathrm{~g} / \mathrm{kg}$, respectively. The flame temperature of $722-947^{\circ} \mathrm{C}$ could be achieved at $\Phi=0.19-1.43$. The difference of profit margin of about IDR 2,000 was higher than utilized LPG as fuel. These parameters meet the requirements of the Indonesian standards (SNI 7926:2013), therefore this stove design is acceptable for small household industry applications. Corncob waste is considered more suitable to utilize as fuel using this biomass cookstove respect to abundant in the local area, low ash content, lower fuel consumption rate, relatively higher thermal power, and easy to ignite.

One of the authors Suhartono would like to thank Ministry of Research, Technology and Higher Education (DPRMRISTEKDIKTI), Indonesia for financial support for carrying out this research through the PTUPT-scheme. The authors would also like to express thanks to the villagers in West Bandung District who have participated in testing and surveys for this study. We also wish to thank Aidil and Sukeni for their assistance in the preparation of technical drawings of stoves.

\section{References}

1. Suhartono, B. D. Prasetyo, I. N. Azizah, J. Eng. Appl. Sci. 11, 8 ( 2016).

2. Suhartono, T. A Putri, L. Fauziah, Int. J. Adv. Sci, Eng. Inf. Tech. 7 (2017).

3. S.C. Bhattacharya, D.O. Albina, A.M. Khaing, Biomass, and Bioenergy. 23 (2002).

4. M. Sharma, H.S. Mukunda, G. Sridhar, Energy Conv. Management. 50, (2009).

5. Indonesian standarization bureau, Indonesia's national standard-performance biomass stove. Jakarta, Indonesia: BSNi (2013).

6. B.M. Jenkins, L.L. Baxter T.R. Miles Jr., T.R. Miles, Fuel Proc. Tech. 54, (1998).

7. D. R. Nhuchhen, M. T. Afzal, Bioengineering. 4, 7 (2017).

8. A. Sharma, E. Terrel, C.S Thegala, Wood and Fiber Sci. 49, 3 (2017).

9. A. Saturday, E.P Sule, E.F OGbona, N.E. Anslem, Int. J. Sc. Dev. Research, 1, 8 (2016).

10. K. Qian, A. Kumar, K. Patil, D. Wang, Energies, 6 (2013).

11. H.A. Dabhi, Int.l J. Sci. Research Dev. 3, 05 (2015).

12. P. Punnarapong, A. Promwungkwa, N Tippayawong, " Energy Proc. 110, (2017).

13. J. Agenbroad, M. DeFoort, A. Kirkpatrick, C. Kreutzer, Energy Sustainable Dev. 15, (2011).

14. S. P. Sood, Y. P. Khandetod, A. G. Mohod, R. M. Dharaskar, K. G. Dhande, Adv. Agr. Research Tech. J. 2, 1,2018.

15. E.A.T. Yuntenwi, N. MacCarty, D. Still, J. Ertel, Energy Sust. Dev. 12, 2 (2008).

16. S. Narnaware, D. Pareek, Int. Energy J.. 15, (2015).

17. E. Adkins, E. Tyler, J. Wang, D. Siriri, V. Modi, Energy Sustainable Dev. 14, (2010).

18. P. Bhusal, B. Bahadur Ale, R.M. Singh, Proc. IOE Grad. Conf. 55-62, (2015).

19. H.S. Mukunda, P.J. Paul, N.K.S. Rajan, S. Dasappa, M. Yagnaraman, D.R. Kumar, M. Deogaonkar, Current Sci. 9, 5 (2010). 
20. W. Jangsawang, K. Laohalidanond, S. Kerdsu, Energy Procd. 79, 520 - 527, (2015).

21. M. Lalovic, Z. Radovic, N. Jaukovic, Materiali in Technologije, 40, 3, (2006).

22. E. Kusrini, A.K. Sasongko, Nasruddin, A. Usman, IJTech. 8, 1436-1444, (2017). 